\section{Cleaning injecting equipment: a message gone wrong?}

\section{Johanna Herrod, Michael Farrell, John Strang}

Clare College, Cambridge Johanna Herrod, PHD, medical student

Drug Dependence Clinical Research and Treatment Unit, Maudsley and

Bethlem Royal Hospitals, London SE5 8AZ

Michael Farrell, MRCPSYCH, research senior registrar John Strang, MRCPSYCH, consultant psychiatrist

Correspondence to

Dr Farrell.

BrMed F 1989;299:601
Over 100 syringe exchange schemes exist in the United Kingdom,' aiming at limiting the spread of HIV among drug users. The main strategy is to reduce sharing of injecting equipment by providing information about HIV and AIDS and supplying sterile equipment. If clean injecting equipment is not available the next best step is to clean used equipment properly. This approach was adopted in San Francisco in a "teach and bleach" campaign. ${ }^{2}$ Cleaning should rid the equipment of any blood products that might contain HIV. The best method is to boil the equipment, but this is rarely done and may damage some syringes. The next best method is to flush soapy cold water, then concentrated bleach, and then further cold water through the equipment, doing each step two or three times; using warm water initially may cause clotting and hence retention of blood products. We assessed knowledge of the recommended technique among drug users and drug workers.

\section{Methods and results}

During February 1989 we interviewed 44 drug takers from the outpatient clinic of a drug dependence unit and a street agency. All had injected drugs at some time. We also did a telephone survey of the needle exchanges in London, asking what advice on cleaning equipment they gave to people.

Describing what they thought was the officially recommended method of cleaning injecting equipment, five drug takers said that the equipment should be boiled for five minutes; 10 that it should be flushed through with boiling water; eight that it should be flushed through with bleach diluted with boiling water; five that it should be flushed through with warm water and washing up liquid; and eight that it should be flushed through with a sterilising agent (Milton), lemon juice, alcohol, or an antiseptic agent (TCP) and boiling water. Eight said that it should be disposed of and new needles and syringes used. Only 10 out of 42 cleaned equipment in a manner that they knew was not recommended; 11 always used new equipment, and 21 followed what they thought was the recommended method. When asked what had influenced them to clean their equipment the way they did 21 said that it was common sense, seven had received information from street agencies, eight had read leaflets, and only three had got their information from a doctor or nurse.

In the telephone survey most agencies admitted to confusion over the most advisable method of cleaning. Many said that they would try to dissuade drug takers from using old equipment. The most common mistake was to recommend flushing with warm water.

\section{Comment}

Reducing harm among drug takers entails providing conflicting messages, such as "Don't share but if you do share clean your works [equipment]." Despite, or probably because of, the effort to provide sterile injecting equipment, the cleaning of dirty equipment is rarely discussed. Sharing injecting equipment has become difficult to discuss. Staff working with drug takers must break this taboo and provide education on the correct cleaning methods.

The fact that $21(48 \%)$ of our subjects thought that they followed the recommended cleaning method and $31(70 \%)$ cleaned their equipment in a manner that might result in retention of blood products emphasises the importance of providing clear instructions on cleaning techniques. Studies have shown that people who inject drugs are amenable to change. ${ }^{3}$ Leaflets containing guidelines on cleaning should be handed out each time injecting equipment is exchanged.

\footnotetext{
1 Farrell M. Conference report: new models of services for drug misusers. Bulletm of the Royal College of Psychiatrists (in press)

2 Newmeyer JA. Why bleach? Fighting AIDS contagion among intravenous drug users; the San Francisco experience. I Psychoactive Drugs 1988:20:169-72.

Stimen G, Dolan $K$, Donoghoe M, Aldritt L Lart R. Syringe exchanges: can Stimson G, Dolan K, Donoghoe M, Aldritt
injectors change? Druglink 1989;4(1):10-1.

(Accepted 3 fuly 1989)
}

Menopause Clinic, Academic Department of Obstetrics and Gynaecology, King's College School of Medicine and Dentistry, London SE5 9PJ

Kevin Gangar, MRCOG, research fellow

Michael Cust, MRCOG, research fellow

Malcolm I Whitehead,

FRCOG, consultant

Correspondence to Mr Gangar.

BrMed f 1989;299:601-2

\section{Symptoms of oestrogen deficiency associated with supraphysiological plasma oestradiol concentrations in women with oestradiol implants}

\author{
Kevin Gangar, Michael Cust, \\ Malcolm I Whitehead
}

Implants are effective for menopausal symptoms ${ }^{1}$ and seem to conserve postmenopausal bone mass. ${ }^{2}$ Thom $e t$ al reported that after implantation of 50 or $100 \mathrm{mg}$ oestradiol "levels of oestradiol with either dose begin to decrease slightly at four months and this change is noticed by many women who feel that the implant has worn off." "' Our interpretation of their data is that the mean plasma oestradiol concentration was $60 \mathrm{pmol} / \mathrm{l}$ before treatment and roughly $300 \mathrm{pmol} / \mathrm{l}$ when symptoms returned.

In a prospective study by Barlow et al of 75 women treated with implants of $50 \mathrm{mg}$ oestradiol either alone or with $100 \mathrm{mg}$ testosterone every six months symptoms recurred when the plasma oestradiol concentrations were above the pretreatment range. ${ }^{4}$ Both groups suggested that symptoms return when the plasma oestradiol concentrations start to fall, not when the pretreatment value has been reached. In addition, Barlow et al reported accumulation of oestradiol, the mean pretreatment value of $175 \mathrm{pmol} / \mathrm{l}$ rising to a mean of $669 \mathrm{pmol} / \mathrm{l}$ at 36 months, six months after the last implantation. ${ }^{4}$

In clinical practice new implants tend to be inserted when symptoms recur. We suspected that if Thom et al and Barlow et al were correct serial implantation based on the recurrence of symptoms might result in some patients eventually developing supraphysiological concentrations of oestradiol but complaining of classic symptoms of oestrogen deficiency. We present data on 12 such patients.

\section{Case reports}

The 12 menopausal patients either had been referred to our clinics having been treated elsewhere or had received all their treatment at our clinics. Reimplantation had been based on the recurrence of vasomotor and psychological symptoms such as mood swings and irritability. All patients had started treatment with implants of $50 \mathrm{mg}$ oestradiol inserted every six months, but many patients had coerced their 


\begin{tabular}{|c|c|c|c|c|c|}
\hline $\begin{array}{l}\text { Case } \\
\text { No }\end{array}$ & $\begin{array}{c}\text { Duration } \\
\text { of } \\
\text { treatment } \\
\text { (years) }\end{array}$ & $\begin{array}{l}\text { Interval between } \\
\text { insertion of } \\
\text { penultimate and } \\
\text { last implants } \\
\text { (months) }\end{array}$ & $\begin{array}{l}\text { Type of implant } \\
\text { last inserted }\end{array}$ & $\begin{array}{l}\text { Interval between } \\
\text { insertion of } \\
\text { last implant } \\
\text { and recurrence } \\
\text { (weeks) }\end{array}$ & $\begin{array}{c}\text { Oestradiol } \\
\text { when } \\
\text { symptoms } \\
\text { recurred } \\
(\mathrm{pmol} / \mathrm{l})\end{array}$ \\
\hline 1 & $2 \cdot 5$ & 3 & Oestradiol $75 \mathrm{mg}$, testosterone $50 \mathrm{mg}$ & 9 & 2325 \\
\hline 2 & 3 & 3 & Oestradiol $75 \mathrm{mg}$ & 12 & 2000 \\
\hline 3 & 7 & 4 & Oestradiol $50 \mathrm{mg}$, testosterone $100 \mathrm{mg}$ & 3 & 1500 \\
\hline 4 & 3 & 2 & Oestradiol $200 \mathrm{mg}$ & $<4$ & 2995 \\
\hline 5 & 0.75 & 4 & Oestradiol $50 \mathrm{mg}$, testosterone $100 \mathrm{mg}$ & 8 & 2400 \\
\hline 6 & 2 & $2 \cdot 5$ & Oestradiol $50 \mathrm{mg}$, testosterone $100 \mathrm{mg}$ & $<4$ & 1450 \\
\hline 7 & 4 & 4 & Oestradiol $100 \mathrm{mg}$, testosterone $100 \mathrm{mg}$ & 12 & 2500 \\
\hline 8 & 7 & 4 & Oestradiol $100 \mathrm{mg}$, testosterone $100 \mathrm{mg}$ & 16 & 1600 \\
\hline 9 & 7 & 7 & Oestradiol $100 \mathrm{mg}$ & $<4$ & $>3500$ \\
\hline 10 & 7 & 5 & Oestradiol $50 \mathrm{mg}$, testosterone $100 \mathrm{mg}$ & 16 & 1900 \\
\hline 11 & 5 & 4 & Oestradiol $100 \mathrm{mg}$ & 6 & 1800 \\
\hline 12 & 3 & 3 & Oestradiol $75 \mathrm{mg}$, testosterone $100 \mathrm{mg}$ & 6 & 1865 \\
\hline
\end{tabular}

doctor into inserting higher doses more frequently because symptoms recurred early.

The table shows the total duration of treatment, the interval between insertion of the penultimate and last implants, the type of implant last inserted, the interval between insertion of the last implant and recurrence of symptoms, and the plasma oestradiol concentrations when symptoms recurred.

\section{Comment}

Troublesome symptoms of oestrogen deficiency (flushes, sweats, mood swings, and irritability) in patients with supraphysiological plasma oestradiol concentrations (above $1200 \mathrm{pmol} / \mathrm{l}$, the periovulatory peak) have not been reported previously. We suspect that this phenomenon is a form of tachyphylaxis, with successive implants relieving symptoms for ever diminishing periods. The mechanism of action is unknown. In adult lower mammals supraphysiological oestradiol concentrations cause major functional changes, possibly due to perineuronal gliosis and glial thickening within the hypothalamus'; similar

\section{Effect of rate of infusion of quinine on insulin and glucose responses in Malawian children with falciparum malaria}

Department of Tropical Diseases, Liverpool School of Tropical Medicine, Liverpool L3 50A

Malcolm E Molyneux, FRCP, senior lecturer

Gregory Harper, BSC,

laboratory technician

Department of Community Health Science, College of Osteopathic Medicine, Michigan State University, Michigan, United States

Terrie E Taylor, Do, assistant professor

Kamuzu Central Hospital, Lilongwe, Malawi Jack J Wirima, MRCP, principal medical specialist

Correspondence to: Dr Molyneux.

BrMed f 1989;299:602-3 anatomical changes that disturb function in the vasomotor centre might occur in postmenopausal women.

Irrespective of the mechanism, the clinical importance of these data is clear: doctors should not rely solely on the recurrence of symptoms to time reimplantation. Some of our patients (cases 1, 2, 4, 12) received implants too frequently (after three months or less). Other patients treated with implants of only $50 \mathrm{mg}$ oestradiol (for example, case 5) received a new implant when symptoms recurred every four months, and yet plasma oestradiol concentrations of $2400 \mathrm{pmol} / \mathrm{l}$ were eventually achieved. Because of these and previous reports of accumulation ${ }^{4}$ we wonder whether plasma oestradiol concentrations should be measured routinely before reimplantation if there is any risk of accumulation.

Optimal management in the cases described here is not known. There are no data to indicate that supraphysiological oestradiol concentrations cause harm. We suspect, however, that further implantation relieves symptoms for ever shorter periods. Our approach has been to withhold all forms of oestrogen until the plasma oestradiol concentration has returned to less than $200 \mathrm{pmol} / \mathrm{l}$. This may take many months, during which the patients suffer intense vasomotor and psychological symptoms, are miserable, and need much support. We then start giving oestrogens in a form that does not cause accumulation.

1 Greenblatt RB, Suran RR. Indications for hormone pellets in the therapy of endocrine and gynecological disorders. Am J Obstet Gynecol 1949;57:294

2 Savvas M, Studd JWW, Fogelman I, et al. Skeletal effects of oral oestrogen compared with subcutaneous oestrogen and testosterone in postmenopausal women. Br Med f 1988;297:331.

3 Thom MH, Collins WP, Studd JWW. Hormonal profiles in postmenopausal women after therapy with subcutaneous implants. Br $\mathcal{f}$ Obstet Gynaecol $1981 ; 88: 426$

4 Barlow DH, Abdalla HI, Roberts AD, et al. Long term hormone implant therapy-hormonal and clinical effects. Obstet Gynecol 1986;67:321.

5 Naftolin F, MacLusky NJ, Lerantyl CZ, et al. The cellular effects of estrogen on neuroendocrine tissues. I Steroid Biochem 1988;29:215-28.

(Accepted l6 May 1989)

phase radioimmunoassay), and quinine (by high performance liquid chromatography) concentrations at zero, one, and three hours after the start of the first infusion of quinine dihydrochloride, which was given intravenously according to the following three regimens: nine patients received $10 \mathrm{mg} / \mathrm{kg}$ infused over three hours (group 1); 10 received $20 \mathrm{mg} / \mathrm{kg}$ infused over three hours (group 2); and 10 received $10 \mathrm{mg} / \mathrm{kg}$ infused over one hour (group 3). Quinine was given in $5 \%(50 \mathrm{~g} / \mathrm{l})$ glucose in half strength Darrow's solution at $80 \mathrm{ml} / \mathrm{kg} / 24 \mathrm{~h}$ in all groups.

The patients in group 2 had a significantly lower mean packed cell volume than those in groups 1 and 3 ( 0.19 compared with 0.29 and 0.32 respectively). There were no significant differences among the three groups in any other variables, including age, duration or pattern of symptoms, physical signs, and additional treatment. At the end of the first hour of treatment the mean (SD) plasma quinine concentrations were $4 \cdot 6$ $(2 \cdot 4), 10 \cdot 1(2 \cdot 4)$, and $13 \cdot 0(3 \cdot 1) \mathrm{mg} / \mathrm{l}$ in groups 1,2 , and 3 , respectively $(\mathrm{F}=20 \cdot 1 ; \mathrm{df}=2,21 ; \mathrm{p}<0.0001$ by analysis of variance). At three hours they were $10 \cdot 1(3 \cdot 4), 17 \cdot 4(3 \cdot 1)$, and $10 \cdot 3(3 \cdot 3) \mathrm{mg} / \mathrm{l}(\mathrm{F}=16 \cdot 9$; $\mathrm{df}=2,24 ; \mathrm{p}<0 \cdot 001)$.

The mean plasma glucose concentration increased slightly but not significantly in each group during observation. None of the patients became hypoglycaemic during the treatment. At the end of the first hour of infusion the mean plasma insulin concentration had risen from $7 \cdot 4(5 \cdot 2)$ to $16 \cdot 6(10 \cdot 9) \mathrm{mU} / \mathrm{l}$ in group 1 , from $5 \cdot 0(3.9)$ to $14 \cdot 1(15 \cdot 3) \mathrm{mU} / 1$ in group 2 , and from $8 \cdot 2(4 \cdot 6)$ to $35 \cdot 5(21 \cdot 1) \mathrm{mU} / \mathrm{l}$ in group $3(\mathrm{~F}=3.93$; $\mathrm{df}=2,23 ; \mathrm{p}<0.05$ by analysis of covariance). At three 